\title{
A Multifaceted Approach to Particle Analysis
}

\author{
H.A. Lowers
}

U.S. Geological Survey, MS 973, Denver, CO 80225-0046

The U.S. Geological Survey has responded to natural and environmental disasters such as the World Trade Center Collapse, Mount St. Helen's 2004 eruption, Hurricane Katrina, LUSI East Java Indonesia Mud Volcano, and the 2007 Southern California wildfires. While these catastrophes produce plentiful sample, not all situations will yield ample material to run unlimited analytical tests. An informative approach to analysis order can minimize the amount of material needed. The USGS uses a combination of x-ray diffraction, x-ray fluorescence, inductively coupled plasma mass spectrometry, and leach tests for complete bulk sample characterization. Electron microscopy is able to assimilate data gained by bulk techniques to link particle size and morphology, phase identification, and chemistry. Data gathered using this approach is better able to predict potential adverse effects to human health and the environment.

An example of this multifaceted approach is given for soil and ash samples collected from burn areas of the October 2007 Southern California wildfires. Bulk sample collection and splitting are described in Hoefen et al. [1], preliminary analytical results are given in Plumlee et al. [2], and leachate chemistry is given in Hageman et al. [3]. The samples are largely composed of soil components such as quartz, feldspar, mica, and calcite and burn products such as arcanite $\left(\mathrm{K}_{2}\left(\mathrm{SO}_{4}\right)\right)$, portlandite $\left(\mathrm{Ca}(\mathrm{OH})_{2}\right)$, and syngenite $\left(\mathrm{K}_{2} \mathrm{Ca}\left(\mathrm{SO}_{4}\right)_{2}\left(\mathrm{H}_{2} \mathrm{O}\right)\right)$ (Table 1 and Fig. 1). Energy dispersive spectroscopy alone could not identify many of the burn phases. Only with the aid of the x-ray diffraction data could the phases be identified.

Based on water leach tests, all samples generated high $\mathrm{pH}$ levels $(>9)$ with residential burn samples having the highest $\mathrm{pH}(>12)$. Portlandite and lime are the components which produce the sample alkalinity. Scanning electron microscopy determined these phases are less than 10 micrometers and often less than 5 micrometers. Particles of this size and composition may pose a risk to human health if inhaled and react with moisture in the respiratory tract.

\section{References}

[1] T.M. Hoefen et al., U.S. Geological Survey OFR 2009-in press (2009).

[2] G.S. Plumlee et al., U.S. Geological Survey OFR 2007-1407 (2007).

[3] P.L. Hageman et al., U.S. Geological Survey OFR 2008-1139 (2008). 
TABLE 1. X-ray diffraction results of white ash collected from the Harris Fire burn area.

\begin{tabular}{|l|c|}
\hline \multicolumn{1}{|c|}{ Phase } & Abundance \\
\hline Calcite $\left(\mathrm{CaCO}_{3}\right)$, Quartz $\left(\mathrm{SiO}_{2}\right)$ & Major $(>25$ wt.\%) \\
\hline Muscovite $\left(\mathrm{KAl}_{2}\left(\mathrm{Si}_{3} \mathrm{Al}\right) \mathrm{O}_{10}(\mathrm{OH}, \mathrm{F})_{2}\right)$, Albite & Minor $(5-25$ wt.\%) \\
$\left(\mathrm{NaAlSi}_{3} \mathrm{O}_{8}\right)$, amorphous material & \\
\hline Arcanite $\left(\mathrm{K}_{2}\left(\mathrm{SO}_{4}\right)\right)$, Portlandite $\left(\mathrm{Ca}(\mathrm{OH})_{2}\right)$, Amphibole & \\
$\left(\mathrm{Ca}_{2}(\mathrm{Mg}, \mathrm{Fe})_{5} \mathrm{AlSi}_{7} \mathrm{O}_{22}(\mathrm{OH}, \mathrm{F})_{2}\right)$, Syngenite & Trace $(<5$ wt.\%) \\
$\left(\mathrm{K}_{2} \mathrm{Ca}\left(\mathrm{SO}_{4}\right)_{2}\left(\mathrm{H}_{2} \mathrm{O}\right)\right)$, Calcium aluminum silicate & \\
$\left(\mathrm{CaAlAl} \mathrm{SiO}_{6}\right)$, Anhydrite $\left(\mathrm{Ca}\left(\mathrm{SO}_{4}\right)\right), \mathrm{Lime}(\mathrm{CaO})$, & \\
Fluorapatite $\left(\mathrm{Ca}_{5}\left(\mathrm{PO}_{4}\right)_{3} \mathrm{~F}\right)$ & \\
\hline
\end{tabular}

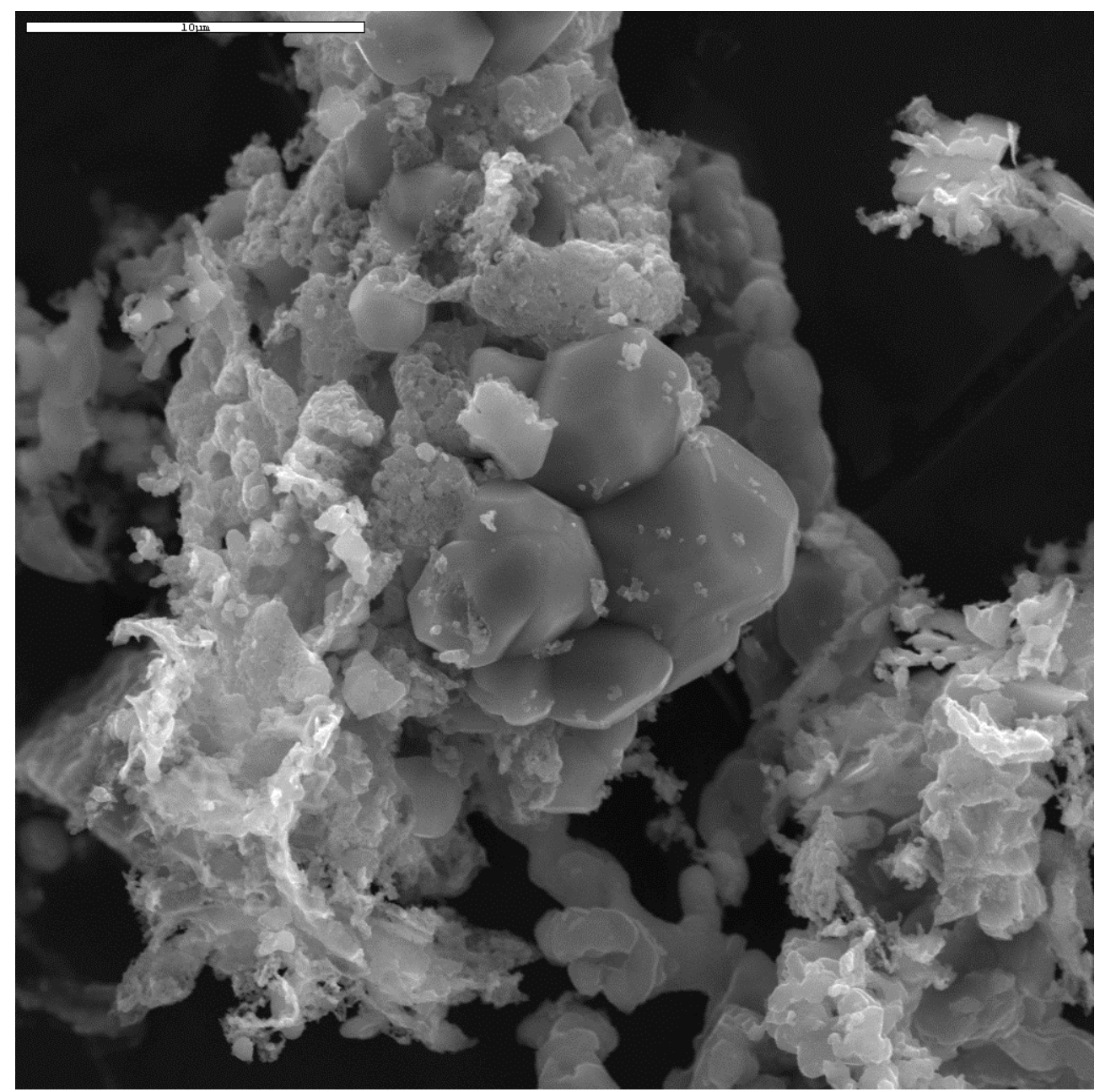

FIG. 1 Secondary electron image of arcanite $\left(\mathrm{K}_{2}\left(\mathrm{SO}_{4}\right)\right)$ found in white ash from the Harris Wildfire burn area. Scale bar is 10 micrometers. 